\title{
スギ花粉症の危険要因に関する症例対照研究
}

\author{
小 笹 晃太郎*1, 竹 中 洋*2, 高 木 伸 夫*2 \\ 青 池是*1, 川 井啓 市*1 \\ ${ }^{* 1}$ 京都府立医科大学公衆衛生学教室 \\ ${ }^{* 2}$ 京都府立医科大学耳鼻咽喉科学教室
}

\section{A Case Control Study of Risk Factors for Japanese Cedar Pollinosis}

\author{
Kotaro OZASA*1, Hiroshi TAKENAKA*2, Nobuo TAKAGI*2, \\ Akira AOIKE*1 and Keiichi KAWAI*1 \\ ${ }^{* 1}$ Department of Preventive Medicine, Kyoto Prefectural University of Medicine, Kyoto \\ ${ }^{* 2}$ Department of Otorhinopharyngolaryngiology, Kyoto Prefectural University of Medicine, Kyoto
}

\begin{abstract}
Risk factors for Japanese cedar pollinosis including past or family history of allergic diseases, smoking and passive smoking, dwelling conditions, and life events were analyzed by a case control method. Patients with Japanese cedar pollinosis (22 males and 67 females) were matched with a corresponding number of patients without potential symptoms of pollinosis according to sex and age ( \pm 5 years). The mean age was 39 years in both groups. The odds ratio (OR) was calculated by McNemar's method and the conditional logistic regression model.

The design and methodology in this study were somewhat inadequate so that the validity of the results is limited. The most important problem was no-matching according to exposure to pollen.

Significantly high OR for past history of allergic disease $(8.80,95 \%$ confidence interval (CI); 3.49-22.2), atopic sermatitis $(9.00,95 \% \mathrm{CI}$; $1.14-71.0)$, and a sibling history of allergic disease $(3.25,95 \% \mathrm{CI}$; 1.06-9.97) were consistent with former genetical studies.

ORs were lower than unity for current smokers $(0.36,95 \% \mathrm{CI} ; 0.11-1.13)$ and those smoking 10 cigarettes/day or more $(0.20,95 \% \mathrm{CI}$; $0.04-0.91)$ relative to nonsmokers. The OR for passive smoking from 7-15 years of age as a result of the father's smoking habit $(0.38,95 \%$ CI; 0.17-0.86) was also significantly low. Smoking was suggested to increase the level of total and antigen-specific IgE in serum by former studies, so that sensitization and symptoms should be studied separately.

The high OR of residents in a business or light industrial area (5.00, 95\% CI; 1.45-17.3) suggested an association with air pollution. The findings such as a high OR for using a gas stove (3.52, 95\% CI; 1.34-9.24), low OR for using an airconditioner $(0.38,95 \% \mathrm{CI}$; $0.16-0.87)$, and a not significant OR for other housing environments, were controversial by comparison with former studies of allergic responses to indoor antigens. "Moving" was the only item with a significantly high OR among the 37 life events. Therefore, it may represent an environmental change rather than mental stress.
\end{abstract}

Reprint requests to: Kotaro Ozasa, Department of Preventive Medicine, Kyoto Prefectural University of Medicine, Kawaramachi Hirokoji, Kamigyo-ku, 602, Kyoto, Japan 
日衛誌 (Jpn. J. Hyg.) 第 50 巻 第 2 号 1995 年 6 月

Key words: Pollinosis (花粉症), Allergy (アレルギー), Case control study (症例対照研究), Risk factor (危険要因), Smoking (喫煙), Lifestyle（生活習慣), Environment（環境）

\section{はじめに}

スギ花粉症は，1964 年に堀口および斉藤 ${ }^{1)}$ が報告した 後,他の鼻アレルギーとともに 1970 年代以後に急速に増 加した ${ }^{2)}$ 。現在の有病率は地域や年齢によって異なるが おおむね 5 〜 $15 \%$ と推定され ${ }^{2 \sim 9)}$, 生活活動を障害する疾 病として国民保健上の重要な問題となっている。

この原因として,まず，第 2 次世界対戦後に植林され たスギが花粉を飛散させる樹齢に一斉に達したことなど によってスギ花粉の飛散量が急激に増加したことが指摘 されている2)。次に, 近年スギ花粉症のみならずアレル ギー疾患が増加していることの原因として, 生活習慣の 変化やそれに伴う体質の変化, 環境の変化などがあげら れている2゙。例えば, 蛋白質搨取量の増加にともなう食物 抗原の増加, 住宅の密閉性の向上や内装材の変化, 室内 居住時間の延長による室内塵由来の吸入抗原の増加, 自 動車排気ガスなどの大気污染とストレスとの関連などが 話題となっている。これらの仮説を証明するためには, 実験による感作発症モデルの研究とともに記述疫学的お よび分析疫学的研究を行って総合的に検討する必要があ るが, 花粉症の危険要因に関する疫学的研究は必ずしも 多くない。本研究ではスギ花粉症の危険要因としての宿 主要因, 生活習慣や生活条件, 生活出来事を明らかにす ることを目的として, 病院外来の受診者を対象とした症 例対照研究を行った。

\section{対象と方法}

1993 年 2 月〜 6 月に京都府立医科大学附属病院耳鼻 咽喉科外来を受診したスギ花粉症患者 89 例を症例とし た。性および年齢は男 22 人, 女 67 人, 平均年齢は 39 歳 で 9 歳から 73 歳に分布していた。症例の上記外来におけ るスギ花粉症の診断時期はすべて 1991 年以後であり 1993 年が $91 \%$ を占めた。

花粉症の診断は自覚症状（くしゃみ，鼻みず，鼻づま り, 鼻がかゆい, 目がかゆい, 涙が出る, 目がごろごろ する）があってスギ花粉特異的 IgE 抗体が証明された者 で, 鼻汁中の好酸球が陽性であるか, 鼻内誘発試験が陽 性である者とした ${ }^{10)}$ 。特異的 $\operatorname{IgE}$ 抗体の検出方法は，皮 内反応, RAST 法または CAP-RAST 法のいずれかであ る $^{10)}$ 。 スギ花粉特異的 $\operatorname{IgE}$ 抗体と同時に他の花粉や室内 塵または室内塵由来のダ二に対する特異的 $\operatorname{IgE}$ 抗体が
検出されても，問診等からスギ花粉が主抗原と判定され た者は症例として採用した。したがって，イネ科花粉症 の合併が $19 \%$, 通年性アレルギー鼻炎の合併は $39 \%$ にみ られた。

対照は, 同年 2 月〜 9 月の同外来を受診した花粉症の 症状を認めない者から性および年齢（土5 歳）をマッチ させて採用した。平均年齢は 39 歳で 8 歳から 69 歳に分 布していた。対照の疾患は, 副鼻腔炎などの慢性炎症性 疾患が $27 \%$, 難聴, 耳鳴またはめまいが $20 \%$, 急性炎症 性疾患が 17\%, 喉頭咽頭部の知覚異常や神経疾患が 12\% であり,そのほかに橋本病などの膠原病, 良性腫瘍, 外 傷などが含まれた。なお, 症例, 対照ともに悪性新生物 の診断を受けた者や，ステロイド剤または免疫抑制剤の 全身投与を行われている者は除外した。

症例および対照には外来受診時に自記式質問票を手渡 して次回の受診時に回収した。質問票の内容は，自覚症 状，アレルギー疾患などの診断歴および家族歴，本人お よび家族の喫煙歴, 発症する直前の住居の状況や生活出 来事 $(37 \text { 項目 })^{11)}$ ，並びに職業である。

対照には質問票の手渡し時に問診で花粉症でないこと を確認した。しかし，質問票の回答内容に花粉症様の症 状がある場合には，外来の耳鼻咽喉科医師の診察によっ て容易に花粉症およびアレルギー鼻炎を否定できる場合 には対照として採用し，できない場合には解析から除外 した。

危険要因のオッズ比は McNemarの方法で求め

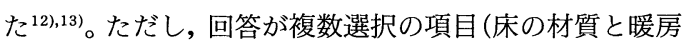

Table 1 Distribution of symptoms.

\begin{tabular}{lcc}
\hline Symptoms & Case (\%) & Control(\%) \\
\hline 1 Sneezing & 93 & 8 \\
2 Rhinorrhoea & 96 & 3 \\
3 Nasal obstruction & 81 & 6 \\
4 Itching of nasal mucosa & 54 & 2 \\
5 Itching of conjunctiva & 78 & 9 \\
6 Shedding tears & 43 & 5 \\
7 Foreign matter sensation of eyes & 27 & 0 \\
Any nasal symptom (1-4) & 100 & 17 \\
Any conjunctival symptom (5-7) & 84 & 12 \\
Any symptom (1-7) & 100 & 24 \\
No symptoms & 0 & 76 \\
\hline
\end{tabular}


の種類) では多変量解析として SAS の LOGISTIC を用 いた conditional logistic regressionによって求めた ${ }^{14)}$ 。

\section{結果}

症例および対照の花粉症の診断基準に挙げられている 症状の有無は Table 1 に示す通りであった。症状が 2

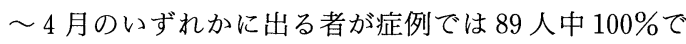

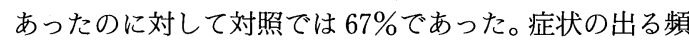
度も症例ではほぼ毎年が $78 \%, 2 〜 3$ 年に 1 度が $4 \%$, 不定が $2 \%$, 去年または今年に初めてが $16 \%$, ほぼ毎 年出る者が多いのに対して, 対照では症状の出る者で頻 度の質問に回答した 20 名中，前述の順に $10 \%$ ，5\%， 60\%, 25\%と不安の者が多かった。また, 症状によって

Table 2 Distribution of age of the first symptom of pollinosis appearing among cases.

\begin{tabular}{ccccccccc}
\hline $\begin{array}{c}\text { Age of the first } \\
\text { symptom appearing } \\
\text { (years of age) }\end{array}$ & $6-12$ & $13-17$ & $18-21$ & $22-29$ & $30-39$ & $40-49$ & $50+$ \\
\cline { 2 - 8 } & 1 & 0 & 0 & 0 & 0 & 0 & 0 \\
$1-5$ & 2 & 1 & 1 & 1 & 0 & 0 & 0 \\
$6-12$ & & 0 & 3 & 3 & 2 & 1 & 0 \\
$13-17$ & & & 3 & 5 & 3 & 0 & 0 \\
$18-21$ & & & & 5 & 8 & 3 & 1 \\
$22-29$ & & & & 6 & 12 & 3 \\
$30-39$ & & & & & & & \\
$40-49$ & & & & & & & & \\
$50+$
\end{tabular}

${ }^{*}$ Unreasonable answer. One case did not answer.
障害される日常活動も，症例では「よく眠れなかった」 が 64\%，「物事に集中できなかった」が $74 \%$ あ゙ったの

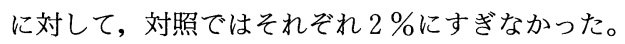

本研究の症例は当耳鼻咽喉科外来で 1991 年以後に花 粉症と診断された患者であるが, 質問票の回答から過去 に花粉症やアレルギー性鼻炎などと診断された者が 61 人あった。また, 調査時の年齢と症状が初発した年萪命の 関係を，質問票で用いた年齢区分で示した（Table 2)。 スギ花粉症の症状が初発した時期がかなり以前に遡る者 が相当数あった。

質問票で把握した各要因の花粉症に対するオッズ比と その信頼区間および対照の要因への曝露率 (89人に対す る\%)を Table 3〜 5 に示した。まず，本人，父母または 兄弟姉妹のアレルギー疾患の診断歴と花粉症様の症状 （Table 3）は花粉症の危険性を高くする傾向にあり，本 人および兄弟姉妹のアレルギー疾患全般の診断歴のオッ ズ比 (8.80 および 3.25$)$ と本人のアトピー性皮膚炎の診 断歴のオッズ比 (9.00) が有意であった。なお, 兄弟姉 妹の解析は症例と対照がともに兄弟姉妹を有する場合に 限った。

喫煙状況では (Table 4)，1日 10 本以上の現在喫煙の 非喫煙に対するオッズ比（0.20）および全対象者の小中 学校の頃の家族による間接喫煙のオッズ比（家族の誰 か：0.45, 父:0.38）がいずれも有意に小さく, 現在喫 煙者の非哭煙者および過去喫煙者に対するオッズ比，過 去喫煙者の非喫煙者に対するオッズ比，非喫煙者の小中 学校の頃の家族による間接喫煙のオッズ比のいずれも小 さい傾向を示した。しかし，非喫煙者の現在の間接喫煙

Table 3 McNemar's odds ratios (OR), 95\% confidence intervals (CI), and percent exposure in controls (\% EX) for the history of allergic diseases, participants and their families.

\begin{tabular}{|c|c|c|c|c|c|c|c|c|c|}
\hline \multirow{2}{*}{$\begin{array}{l}\text { History of diseases } \\
\text { or symptoms }\end{array}$} & \multicolumn{3}{|c|}{ Participants } & \multicolumn{3}{|c|}{ Father or mother } & \multicolumn{3}{|c|}{ Sibling } \\
\hline & OR & $95 \% \mathrm{CI}$ & $\% \operatorname{EX}(\%)$ & OR & $95 \% \mathrm{CI}$ & $\% \operatorname{EX}(\%)$ & OR & $95 \% \mathrm{CI}$ & $\% \mathrm{EX}(\%)$ \\
\hline Allergic disease in general & 8.80 & $3.49,22.2$ & 16 & 1.50 & $0.52,5.32$ & 10 & 3.25 & $1.06,9.97$ & 19 \\
\hline Bronchial asthma & 5.00 & $0.58,42.8$ & 1 & NA & & 2 & 1.33 & $0.30,5.94$ & 3 \\
\hline Urticaria & 6.00 & $0.72,49.8$ & 4 & 2.00 & $0.18,22.1$ & 3 & 1.00 & $0.06,16.0$ & 2 \\
\hline Atopic dermatitis & 9.00 & $1.14,71.0$ & 3 & NA & & 1 & 2.00 & $0.18,22.1$ & 7 \\
\hline Allergic rhinitis & - & & & 0.50 & $0.05,5.51$ & 2 & 2.00 & $0.37,11.0$ & 2 \\
\hline Allergic conjunctivitis & - & & & 1.00 & $0.06,16.0$ & 1 & NA & & 0 \\
\hline Pollinosis & - & & & 1.00 & $0.06,16.0$ & 2 & 4.00 & $0.85,18.8$ & 7 \\
\hline Symptom like pollinosis & - & & & 2.00 & $0.68,5.85$ & 11 & 2.40 & $0.85,6.81$ & 9 \\
\hline
\end{tabular}

NA: Not available because of an empty cell in a discordant pair.

-: Disease or symptom included in pollinosis itself. 
Table 4 McNemar's odds ratios (OR), 95\% confidence intervals (CI), and percent exposure in controls (\% EX) for smoking.

\begin{tabular}{|c|c|c|c|c|}
\hline Smoking status & $\mathrm{CR}$ & $95 \% \mathrm{CI}$ & $\% \mathrm{EX}(\%)$ & Reference category \\
\hline \multicolumn{5}{|l|}{ Active smoking in all participants } \\
\hline \multirow[t]{2}{*}{ Current smoking } & 0.36 & $0.11,1.13$ & 17 & Nonsmoking \\
\hline & 0.50 & $0.05,5.51$ & & Ex-smoking \\
\hline 10 cigarettes/day or more & 0.20 & $0.04,0.91$ & 16 & Nonsmoking \\
\hline Ex-smoking & 0.57 & $0.17,1.95$ & 11 & Nonsmoking \\
\hline \multicolumn{5}{|l|}{$\begin{array}{l}\text { Passive smoking at present time } \\
\text { in nonsmokers }\end{array}$} \\
\hline Someone in family or workplace & 1.00 & $0.35,2.85$ & $69^{*}$ & No passive smoking \\
\hline \multicolumn{5}{|c|}{$\begin{array}{l}\text { Passive smoking from } 7-15 \text { years of age } \\
\text { in all participants }\end{array}$} \\
\hline Someone in family & 0.45 & $0.21,0.95$ & 77 & No passive smoking \\
\hline Father & 0.38 & $0.17,0.86$ & 66 & do \\
\hline Mother & 0.50 & $0.05,5.51$ & 8 & do \\
\hline Grandfather or grandmother & 0.20 & $0.02,1.17$ & 12 & do \\
\hline \multicolumn{5}{|l|}{ in nonsmokers } \\
\hline Someone in family & 0.50 & $0.20,1.24$ & $73^{*}$ & No passive smoking \\
\hline Father & 0.43 & $0.17,1.12$ & 64 & do \\
\hline Mother & NA & & 3 & do \\
\hline Grandfather or grandmother & 0.33 & $0.03,3.17$ & 14 & do \\
\hline Sibling & 0.50 & $0.50,5.51$ & 12 & do \\
\hline
\end{tabular}

*: Percent of nonsmokers.

Table 5 McNemar's odds ratios (OR), 95\% confidence intervals (CI), and percent exposure in controls (\% EX) for household status.

\begin{tabular}{|c|c|c|c|}
\hline Dwelling condition & OR & $95 \% \mathrm{CI}$ & $\% \mathrm{EX}(\%)$ \\
\hline \multicolumn{4}{|l|}{ Area of residence } \\
\hline Residential area & 0.47 & $0.19,1.15$ & 70 \\
\hline Business or light industrial area & 5.00 & $1.45,17.3$ & 7 \\
\hline Heavy industrial area & NA & & 0 \\
\hline Rural area & 0.50 & $0.05,5.51$ & 2 \\
\hline \multicolumn{4}{|l|}{ Type of house } \\
\hline Wooden house without aluminum window sash & 1.08 & $0.49,2.37$ & 15 \\
\hline Wooden house with aluminum window sash & 0.78 & $0.42,1.45$ & 39 \\
\hline Concrete single house & 2.50 & $0.97,6.44$ & 7 \\
\hline Concrete apartment house & 0.82 & $0.40,1.66$ & 25 \\
\hline \multicolumn{4}{|l|}{ Material of floor } \\
\hline Tatami mat & $1.51^{*}$ & $0.70,3.28$ & 56 \\
\hline Wood & 0.73 & $0.32,1.69$ & 31 \\
\hline Carpet & 1.33 & $0.61,2.91$ & 36 \\
\hline \multicolumn{4}{|l|}{ Type of heating } \\
\hline Central heating & $0.35^{*}$ & $0.07,1.78$ & 7 \\
\hline Airconditioner & 0.38 & $0.16,0.87$ & 38 \\
\hline Electric heater & 0.69 & $0.31,1.56$ & 22 \\
\hline Gas stove & 3.52 & $1.34,9.24$ & 12 \\
\hline Oil stove & 0.82 & $0.35,1.92$ & 43 \\
\hline Charcoal or coal & NA & & 0 \\
\hline
\end{tabular}

*: Odds ratio calculated by multivariate conditional logistic regression because participants were required to choose one or two items as answers. 
のオッズ比は 1.00 であった。

職業では，管理職，専門技術職，専務職，販売職，技 能労務職, 農林漁業職, 通信運輸職, サービス職, 保安 職, 主婦, 学生, 無職, およびその他に分類したとき, 当該職業のそれ以外の職業に対するオッズ比では，無職 (0.22，95\%信頼区間：0.05〜1.02) が最も強い関連を示 したにすぎなかった。

住宅の状況 (Table 5) では, 居住地が住宅地域のオッ ズ比 (0.47) が小さく, 商業・軽工業地域 (5.00) が有 意に高かった。建築様式では鉄筋 1 戸建てのオッズ比 (2.50) が高い傾向を示した。室内の床の材質は有意では なかった。暖房器具ではエアコンのオッズ比 (0.38) が 有意に低く, 室内でガスを燃焼させる暖房器具 (3.52) が有意に高かった。

生活出来事尺度では引つ越しをしたことのオッズ比 (6.00, 同：1.77〜20.4) が有意に高かったほかは，有意 なものはなかった。出来事の数でも，1～ 5 のいずれの 数を限界值としてその上下を比較しても，多い方がオッ ズ比が高い傾向は示したが有意ではなかった。

\section{考察}

本研究は症例対照研究の手法を用いたが，疾病の特徵 や研究実施環境によって研究計画に問題となる点が多い ので, まず, それらについて考察し, ついで解析対象と した要因について考察する。

\section{1 ) 研究計画}

\section{1-1）スギ花粉への曝露の制御}

スギ花粉症では，まず，空中を浮遊するスギ花粉への 曝露が necessary cause ${ }^{12)}$ である。スギ花粉に曝露され た上でスギ花粉による感作とスギ花粉症の発症に影響す る要因を評価するためには，対照は症例と同程度にスギ 花粉に曝露された者から採用することが必要である。ス ギ花粉への曝露の強さをマッチさせるためには，居住地 や勤務地などが症例と近接している必要がある。本研究 では後述する理由により，対照の受診時期と居住地を マッチさせることができなかった。この点が本研究計画 の重大な瑕疪である。しかし，次に示す 2 点から，この 欠点をある程度は補完することが可能であると考える。

まず，花粉飛散量について考える。京都府花粉情報セ ンターでは, 京都市 6 力所, 京都府下 11 力所, 滋賀県 5 力所，大阪市 1 力所，神戸市 1 力所，三重県 1 力所の観 測定点から，花粉飛散シーズン中の毎日の花粉飛散量の 観測結果を得ている ${ }^{15)}$ 。このうち京都市内の 5 力所の 1989 年から 1994 年までの飛散数は，各年ごとの施設間
Table 6 Amount of Japanese cedar pollen suspended in air $\left(\mathrm{pollen} / \mathrm{cm}^{2}\right)$ at five medical facilities in Kyoto city, 1989 -1994 .

\begin{tabular}{|c|c|c|c|c|}
\hline Year & Mean & S.D. & \multicolumn{2}{|c|}{ Range (min, $\max$ ) } \\
\hline 1989 & 141 & 42 & ( 67, & 163) \\
\hline 90 & 1,382 & 591 & ( 896 , & $1,830)$ \\
\hline 91 & 3,419 & 1,626 & $(2,335$, & $6,197)$ \\
\hline 92 & 394 & 171 & ( 274, & 678) \\
\hline 93 & 4,820 & 836 & $(3,499$, & $6,201)$ \\
\hline 94 & 299 & 47 & ( 151 , & 341) \\
\hline Total & 10,456 & 2,539 & $(8,213$, & $13,654)$ \\
\hline
\end{tabular}

Calculated from the data of the Kyoto Pollen Information Center ${ }^{15)}$

のばらつきは大きいが， 6 年間の総数は約 1.7 倍の範囲 内にとどまっている (Table 6)。また，1993 年の全定点 の観測結果は平均 2,066, 標準偏差 644, 最小値 1,262, 最大值 3,395 であった。これらの観測結果から，スギ花 粉は都市から遠い山林地域を発生源としてかなり広い地 域に飛散するので，本観測定点の地域内での花粉飛散量 にばらつきはあるものの, 曝露の有無が問題になるほど の大きな水準の差にはならないと推測できるが，必ずし も地域差を否定できない。このことは，スギ花粉飛散量 と感作の強さの関連が, 飛散の地域的分布より経時的(季 節的または経年的）分布との関連のほうが問題にされて

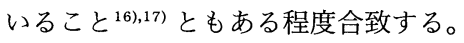

次に, 解析対象である要因がスギ花粉飛散状況と交絡 しないのであれば，それらの要因の対照での分布は対照 がスギ花粉に暴露されていてもいなくても同じである。 本研究で扱った要因が花粉飛散と関連するとは考えにく いために，ある程度は要因の評価が可能であると思われ る。しかし, 研究計画の時点で交絡のないことを仮定す ることは，計画の瑕疵であると言わざるを得ない。

$1-2$ ）遺伝素因

スギ花粉症の遺伝要因についてはスギ花粉抗原に対す る低応答性が単純優性遺伝するという考え方など，遺伝 素因があることは間違いないと考えられているものの， 抗原特異的反応とアトピー素因一般との関連も含めてま だ一元的に解明されていない(18),19)。したがって, 今後, 遺 伝素因が necessary cause として確立され，遺伝素因を 表現する適切な指標が見いだされるまでは，遺伝素因に 関する risk indicator も解析対象に含んだ疫学モデルと して検討する必要があろう。 
$1-3$ ) 有病症例の取扱い

本研究の症例は, 大学附属病院の耳鼻咽喉科の外来受 診者で最近に花粉症の確定診断を受けた者を採用した。 発症前の危険要因を調查することを目的とした症例対照 研究ではできるだけ最近の発症例を採用すべきであるこ とは言うまでもない。有病症例を採用すると，危険要因 が疾病を発病したことによって変化している可能性のた めに正確に評価できないおそれがある。本研究の対象者 は 1993 年の初診者が $91 \%$ あ゙あたにも関わらずその年 または前年に発症した者は $16 \%$ と少なく, 多くの者は数 年以上の有症状期間を近医や薬局などでの治療を受けた か, 放置していた後に来診した。したがって, 個々の危 険要因について発症後の変化の可能性について考察する 必要がある。さらに，有病率が 5 〜 $15 \%$ と推定されてい る common disease である花粉症患者全体の中で, 本研 究の症例が大学附属病院まで受診するという意味で偏つ た集団であることは否めないが，この偏りは対照も同じ であると考えられる。

$1-4)$ その他の問題点

対照の選択に関する他の偏りとして, 病院対照である ために種々の耳鼻科的疾患を有することや, 質問票の手 渡し時に花粉症でないことをあらかじめ確認したにもか かわらず，質問票には花粉症を否定できない症状を回答 した受診者が続出したために，対照の候補者がかなり限 定されたことがある。後者は受診時期や居住地のマッチ ングを困難にした主たる理由である。これらの偏りは 個々の要因の対照での曝露率からその性質を検討する必 要がある。

次に，対照のスギ特異的 $\operatorname{IgE}$ 抗体が陰性であることを 確認できていないことがあげられる。この場合，対照中 のスギ特異的 $\operatorname{IgE}$ 抗体陽性者の割合が大きくなると感 作に関わる要因のオッズ比は 1 に近づく。

\section{2 ) 危険要因の評価}

\section{2-1）遺伝素因}

危険要因として，まず，本人や血縁者（父母，兄弟姉 妹）のアレルギー疾患の既往歴や，血縁者の花粉症様の 症状があげられた。これらは遺伝素因の risk indicator であると考えられる。本研究で父母よりも兄弟姉妹の方 で関連が強かったのは，父母の世代では花粉飛散量の急 増以前に発症の好発年齢を過ぎていたか，高年齢者の対 象者の父母では死亡していたのではないかと考えられ る。

2-2) 喫 煙

本研究の喫煙曝露に関する偏りとして研究計画で述べ
たことの他に，まず，花粉症を発症したために喫煙を中 止したり，喫煙環境を意識的に避けているために，症例 の喫煙率や間接喫煙への曝露率が偏つて低い可能性があ る。しかし，過去喫煙者が症例と対照で同数 (10人) で あり，症例では過去に喫煙経験のない非喫煙者の割合が 大きい。小中学校の頃の間接喫煙は多くの人にとって花 粉症発症以前の曝露状況である。現在の喫煙に関する健 康意識を考慮すると,むしろ症例の方で思い出しに関す る偏りが作用して懪露率が高くなりそうであるが，実際 には逆である。

次に, 対照の喫煙率や間接喫煙への曝露率が偏つて高 い可能性がある。しかし, 現在の成人喫煙率をおおむね 男 $60 \%$, 女 $13 \%{ }^{20)}$ として, 本研究の対照の現在喫煙者数 の期待值を算出すると約 20 人となり, 本研究での実測数 15 人はむしろ小さい。また, 非喫煙者の間接喫煙の曝露 率 $(69 \%)$ と小中学校の頃の間接喫煙への曝露率（家族 の誰か：77\%, 父：66\%）は, 現在の男性の喫煙率（約 $60 \%$ ）や職場での禁煙実施状況（大手企業の全業種で $46 \%)^{21)}$ ，および 1960 年代のわが国の男の喫煙率が最高 約 $80 \%$ であったこと ${ }^{20)}$ から必ずしも高すぎないと思わ れる。

これらのことから研究計画の項で述べた問題が満たさ れるならば, 喫煙が花粉症の発症に抑制的に作用する可 能性が示唆される。

喫煙の影響を花粉症の感作と発症の機序から考察する と，まず，喫煙または間接喫煙によって総 $\operatorname{IgE}$ 值が高く なることはよく知られているが, その機序については, たばこ煙中に感作物質が存在するのか，たばこ煙による 気道系の炎症によって抗原の吸収が促進されるのか, 気 道系の感染が誘発されてさまざまな特異的 $\operatorname{IgE}$ 抗体が 産生されるのか議論の余地がある ${ }^{22)}$ 。特異的なアレル ギー反応については, 間接喫煙によって子供の種々の抗 原に対する皮膚反応が促進されたりダニ特異的 $\operatorname{IgE}$ が 高值を示した報告 ${ }^{23), 24)}$ や，契煙者で肺炎球菌に対する特 異的 $\operatorname{IgE}$ が高值を示した報告 ${ }^{25)}$ がある一方で, 間接喫煙 が子供の皮膚反応や特異的 $\operatorname{IgE}$ 抗体の産生を促進しな

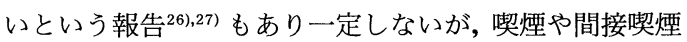
が特異的 IgE の産生を促進する可能性がある。

花粉症の発症には花粉による感作（特異的 $\operatorname{IgE}$ 抗体の 産生）と発症という2つの段階があるが，上述の報告は 主に感作に関する研究であり, 喫煙と発症の関連は不明 である。スギ花粉に感作されて特異的 $\operatorname{IgE}$ の高值である 者が発症する危険性の高いことは報告されているが, 発 症に関与する要因は検討されていない28)。一方, モルモッ 
トの鼻粘膜に亜硫酸ガスやウイルスを作用させて炎症を 起こした場合には，鼻粘膜のヒスタミン刺激による過敏 性が低下したという報告がある29),30)。したがって,たばこ 煙による鼻粘膜での炎症反応が，抗原の吸収を促進させ ることによってスギ花粉に感作させて特異的 $\operatorname{IgE}$ 值を 上昇させるが，粘膜の過敏性は低下させて症状の発現に は抑制的に作用する可能性などが考えられる。今後は適 切な疫学研究および動物モデル実験などによって感作と 発症の段階を区別して評価することが望まれる。 $2-3$ ) 居住条件

住居が商業・軽工業地域にあることのオッズ比が有意 に高かったことは, 大気污染との関連を示唆し, 過去の 報告とも一致するが5),31 33) その機序の解明などは今後の 課題である。なお，居住地をマッチングした場合には， この要因は必然的に一致するために評価できない。

住居の建築様式は, 室内塵由来のダニ $\operatorname{IgE}$ 抗体 ${ }^{34)}$ と室 外から飛来するスギ花粉 $\operatorname{IgE}$ 抗体 ${ }^{35)}$ が，それらの抗原の 挙動が異なるにもかかわらず，ともに鉄筋・鉄骨住宅で 高值になることが報告されている。本研究では $\operatorname{IgE}$ 值で はなく花粉症の有無に関してではあるが，鉄筋・鉄骨の 集合住宅を除いて同様の結果が得られた。また，住宅の 床がじゅうたんの場合にダニ $\operatorname{IgE}$ 抗体は高値を示す36) が，スギ花粉 IgE 抗体は高值を示さず35)，本研究でも畳 やじゅうたんはやや高いオッズ比を示すものの有意では なかった。ダニ抗原とスギ花粉の感作に共通する要因は アレルギー疾患全般を引き起こしやすい体質を作ってい ると考光られるが，過去のスギ花粉の感作に関する研究 と異なった傾向の結果が本研究に見られる場合には，本 研究の症例の約 4 割が通年性アレルギー鼻炎を合併して いたために本研究の結果が通年性アレルギー鼻炎の危険 要因を検出した可能性がある。

本研究では花粉症に対するガス暖房のオッズ比が有意 に高く, ガスに比べて燃焼排ガスの中に微細な煤塵が含 まれていると思われる石油暖房のオッズ比が高くなかっ たことは，花粉症を発症したために䁔房を石油からガス に変えたというような偏りの可能性を示唆する。また， 室内塵由来のダニ $\operatorname{IgE}$ 抗体についてエアコンの使用が 密閉性の高い住宅構造と関連して抗原の増加と拡散に寄 与して IgE を高值にさせる要因と考えられたこと ${ }^{37)}$ が, 一般のメディアを通じて知られるようになり，アレル ギー疾患の診断歴の多い本研究の症例がエアコンを避け た可能性も否定できない。しかし，いずれも検証できな かった。

\section{$2-4$ ）生活出来事尺度}

この指標はストレスの評価として用いたが，有意と なった項目が引っ越しだけであったので，むしろ抗原嚗 露にかかわる環境の変化としての意義の方が大きいかも しれない。ストレスの増加がアレルギー疾患の増加の要 因と考えられている2)ことは確かであるが，ストレスの 適切な評価法も含めてその影響を検討することはむずか しい問題である。

\section{3 ) まとめ}

本研究は方法論上の問題点を多く含むために，その結 果は慎重に解釈する必要がある。スギ花粉症において感 作と発症に異なった要因が関与している可能性が示唆さ れるので，適切な計画による今後の研究が必要である。

\section{謝辞}

外来での質問票調查に全面的な御協力をくださいまし た，京都府立医科大学耳鼻咽喉科学教室の村上泰教授を はじめとする先生方に深甚な謝意を表します。

本研究の一部は第 64 回日本衛生学会総会（1994 年 4 月，金沢）および第 6 回日本アレルギー学会春季臨床大 会（1994 年 4 月，熊本）で報告した。

\section{引用文献}

1）堀口申作，斎藤洋三：栃木県日光地方におけるスギ 花粉症 Japanese cedar pollinosis の発見，アレル ギー, 13，16-18 (1964).

2 ) 奥田 稔：鼻アレルギー(第 2 版)，pp.113-137，金 原出版, 東京 (1992).

3 ）中村 晋：大学生並びに大学職員における杉花粉症 の頻度調査成績，アレルギー，39，476-482(1990)。

4 ）斉藤洋三: 花粉症治療の最近の話題，内科， 59, 677-681 (1987).

5 ）井上 栄, 坂口雅弘, 森田盛大，庄司俊雄，金田誠 一, 木村英二, 山本保男, 井上博雄, 小野哲郎, 道 家直, 平川浩資：一般住民のスギ花粉特異 $\mathrm{IgE}$ 抗体 保有率の地域差, 医学のあゆみ, 145, 121-122 (1988).

6 ）鈴木修二，千葉響子，玉川鐵雄，西田琇太郎，坂口 雅弘, 井上 栄, 宮本昭正：都内事業所 3 集団に打 ける抗スギ花粉 $\operatorname{IgE}$ 抗体值と花粉症症状，アレル ギー，36，587（1987）.

7 ）宮沢 博，坂口雅弘，井上 栄，鈴木修二：一般成 人におけるスギ花粉特異的 $\operatorname{IgE}$ 抗体保有と症状と の関係，アレルギー，38，890（1989）.

8 ) Ishizaki, T., Koizumi, K., Ikemori, R., Ishiyama, 
Y. and Koshibiki, E: Studies of prevalence of Japanese cedar pollinosis among the residents in a densely cultivated area, Ann. Allergy, 58, 265 -270 (1987).

9 ) 九嶋 敦, 大橋裕二, 小泉一裕, 井上 栄, 坂口雅 弘：栃木県日光地区に扔けるスギ花粉症の出現頻 度, アレルギー，36，588 (1987)。

10）奥田 稔：鼻アレルギー(第 2 版), pp.138-208, 金 原出版, 東京 (1992).

11）宗像恒次：新版行動科学からみた健康と病気, p.9, メヂカルフレンド社, 東京 (1990).

12) Rothman, K.J.: Modern epidemiology, pp.7-21, pp.250-274, Little, Brown and Company, Boston (1986).

13) Schlesselman, J.J.: Case-control studies-design, conduct, analysis, Oxford University Press, New York (1982). (重松逸造監訳：疫学・臨床医学のため の患者対照研究, pp.198-202, ソフトサイエンス社, 東京, 1983).

14) SAS Institute Inc. SAS/STAT User's Guide, Version 6, Fourth edition, Volume 2, pp.1122 -1125, SAS Institute Inc., Cary (1990).

15）斎藤憲治：スギ花粉飛散と症状について, 耳鼻臨, 76 , 補冊 (印刷中).

16）前田裕二, 安枝 浩, 剣田幸子, 信太隆夫：飛散ア レルゲンの量とアレルギー患者の感作状態との関連 について，アレルギー，37，919-925 (1988).

17）小川 保, 石井譲治, 三谷一憲, 今井昌雄, 今岡浩 一, 井上 栄: スギ花粉症患者における血中特異抗 体濃度の経時変化, Bull. Inst. Public Health， 41, 404-406 (1992).

18）白川太郎：アトピーの遺伝子, 細胞工学, 11, 906-913 (1992).

19）松下 祥: 花粉症の遺伝要因, Pharma Medica, 12, 19-23 (1994).

20）厚生省編：喫煙と健康 (第 2 版), pp.268-269, 保健 同人社，東京 (1993).

21）宮崎恭一，野上浩志，大島 明，中村正和：わが国 の職場の分煙・禁煙状況，日本公衛誌，39（10，特 別付録)，44（1992）。

22）白川太郎, 森本兼暴：ライフスタイルとアレルギー 反応，(森本兼暴：ライフスタイルと健康), pp.83100, 医学書院, 東京 (1991).

23) Ronchetti, R., Bonci, E., Cutrera, R., DeCastro, G.,
Indinnimeo, L., Midulla, F., Tancredi, G. and Martinez, F.D.: Enhanced allergic sensitisation related to parental smoking, Arch. Dis. Child, 67, 496-500 (1992).

24）逢坂文夫, 春日 斉, 杉田 稔, 松木秀明, 三宅 健 : 学童の血清ダニ $\mathrm{IgE}$ と母の喫煙習慣との関係の研 究, 日衛誌, 40, 1789-1794 (1985)。

25) Bloom, J.W., Halonen, M., Dunn, A.M., Pinnas, J. L. and Burrows, B.: Pneumococcus-specific immunoglobulin $\mathrm{E}$ in cigarette smokers, Clin. Allergy, 16, 25-32 (1986).

26) Arshad, S.H. and Hide, D.W.: Effect of environmental factors on the development of allergic disorders in infancy, J. Allergy Clin. Immunol., 90, 235-241 (1992).

27) Ownby, D.R. and McCullough, J.: Passive exposure to cigarette smoke does not increase allergic sensitization in children, J. Allergy Clin. Immunol., 82, 634-638 (1988).

28）中村 晋：大学生の入学時と 4 年次における杉花粉 症有病率の推移に関する調査成績, アレルギー, 42, 101-106 (1993).

29）雨皿 亮, 鵜飼幸太郎, 坂倉康夫 : 亜硫酸ガス暴露 モルモット鼻粘膜のヒスタミンに対する過敏性およ び反応性の検討，アレルギー，37，40-46（1988）。

30）雨皿 亮, 鵜飼幸太郎, 坂倉康夫：モルモット鼻粘 膜非特異性過敏性抢よび反応性に及ぼす上気道ウイ ルス (HVJ) 感染の影響, アレルギー, 37, 140-146 (1988).

31）横山榮二, 山内厳雄：自動車排出ガスの健康リスク, 公衆衛生研究 (Bull. Inst. Public Health), 41, 324-334（1992）.

32）石山康子, 池森享介, 小泉一弘, 石崎 達: 大気污 染のスギ花粉症に及ぼす影響, 環境別花粉数測定と の関係, アレルギー, 35, 892 (1986).

33）高木 学: 小児期におけるスギ花粉感作の研究, 第 1 編小児気管支喘息におけるスギ花粉感作に影響を 及ぼす環境因子の検討, アレルギー, 37, 1065-1071 (1988).

34）逢坂文夫, 春日 斉, 杉田 稔, 松木秀明, 三宅 健： 学童における血清ダニ $\operatorname{IgE}$ 抗体と居住環境との関 係の研究（第 1 報）住宅環境との関係について, 日 本公衛誌，32，731-737 (1985).

35）逢坂文夫, 春日 斉, 杉田 稔, 松木秀明,三宅 健： 
日衛誌(Jpn. J. Hyg.) 第 50 巻 第 2 号 1995 年 6 月

学童における血清スギ $\operatorname{IgE}$ 抗体と居住環境との関 係について，アレルギー，36，72-80 (1987).

36）逢坂文夫, 春日. 斉, 杉田 稔, 松木秀明, 三宅 健 : 学童における血清ダニ $\operatorname{IgE}$ 抗体と居住環境との関 係の研究（第 2 報）室内環境との関係について, 日
本公衛誌，33，3-11（1986）.

37）逢坂文夫, 春日 斉, 杉田 稔, 松木秀明, 三宅 健 : 学童における血清総 $\operatorname{IgE}$ 抗体と暖房器具との関係 について，日衛誌，41，593-600 (1986).

（受付 1994 年 5 月 16 日 受理 1994 年 11 月 7 日) 